\title{
Nutritional Value of Lupine in the Diets for Pigs (a Review)
}

\author{
Bohumila Písaříková, Zdeněk Zralý \\ Veterinary Research Institute, Brno, Czech Republic \\ Received November 6, 2008 \\ Accepted March 9, 2009
}

\begin{abstract}
The seeds of sweet lupine cultivars (Lupineus species) have been used with increasing frequency as a source of proteins replacing proteins of animal origin or soybean in feed compounds. The seeds of sweet lupine cultivars contain an average of about $33-40 \%$ crude protein in dry matter, the lipid content ranges from 5 to $13 \%$. The profile of amino acids is relatively beneficial, however, with slightly lower content of lysine (1.46\%) and methionine $(0.22 \%)$. The main storage carbohydrates in the seeds are the $\beta$-galactans that comprise most of the cell-wall material of the kernel and the cellulose and hemicellulose of the thick seed coats. Lupine seeds contain about $40 \%$ non-starch polysaccharides (NSP) and a negligible amount of starch. High coefficient of protein digestibility $(>90 \%)$ has been reported in sweet lupine cultivars, but lower digestibility of energy $(\sim 60 \%)$. Lupineus species contain negligible amounts of trypsin inhibitor so they do not require preheating before being used as an ingredient in feeds for monogastric animals. The efficiency of lupine seeds in the diets for pigs is characterized by controversial results of growth and feed conversion under both mechanical treatment and enzyme supplementation. The results of production efficiency obtained at the testing of lupine cultivars (L. albus, L. angustifolius) for pigs were beneficial at supplementation of the lacking nutrients or dehulling. The submitted paper summarizes national as well as foreign knowledge of the nutritive value of cultural lupine seeds, and deals with the possibility increasing nutrition and production efficiency in the diets for pigs.
\end{abstract}

Lupineus sp., crude protein, oligosaccharides, nutrients, antinutritive effect, enzymes, production efficiency

Lupine has been included among eight potential vegetable sources of protein for the use in feed and food that replace proteins of animal origin in the diets (Dijkstra et al. 2003). The yield of 3,000 to $5,000 \mathrm{~kg} /$ ha seeds results in a potential production of up to $2,000 \mathrm{~kg} /$ ha protein.

The world producer and exporter of lupine seed is Australia, whose production represents $80-85 \%$ of global production, of which $90-95 \%$ is exported (White et al. 2007). In 20052006 Australian production exceeded 1 million tons of low-alkaloid lupine, of which more than 300,000 tons were for their own consumption and the rest was exported to the whole world including Europe. Approximately $40 \%$ of the exported lupine seed is used as feed for dairy and meat-type cattle, $40 \%$ as feed for pigs feed and the rest is equally distributed for the nutrition of sheep, goats and poultry (White et al. 2007). In Europe, the main growing areas can be found in Germany, France, Benelux, Spain, Poland, Ukraine and Russia.

At present, so called "sweet" lupine variants are being cultivated, in which the content of bitter substances does not exceed $0.05 \%$. A very low content of nutritive-active factors, low allergenicity and a positive impact on prevention of cardiovascular diseases (hypocholesterolaemic effects and anti-hypertensive activity) have been reported in these cultivars, which leads to their increased use in feed and food industry (Martins et al. 2005).

In the Czech Republic we lack precise data on lupine cultivation. According to the estimation of the company Agritec Šmperk Ltd., the lupine growing area could reach up to 7,000 ha, with an average yield of about $3,100 \mathrm{~kg} / \mathrm{ha}$ on some farms. White lupine (L. albus L.), narrow-leafed lupine (L. angustifolius L.) and yellow lupine (L. luteus L.) are the most frequent species cultivated in the Czech Republic. At present, most of the lupine production is intended as components of feed compounds; whilst the market with

Address for correspondence:

Ing. Bohumila Písaříková

Veterinary Research Institute

Hudcova 70, 62100 Brno, Czech Republic
Phone: +420 533331616

Fax: +420 541211229

E-mail: pisarikova@vri.cz

http://www.vfu.cz/acta-vet/actavet.htm 
lupine seed for food industry is still being developed. The importance of lupine cultivation can also be seen in the EU policy supporting the HEALTHY-PROFOOD research project (Anonymous 2008).

\section{Species, cultivation, physical and chemical characteristics and basic analyses}

The genus of lupine (Lupineus L.) belongs to the family Fabaceae - fabaceous (leguminous), subfamily Genisteae (Šikula and Zubrický 1964). The genus comprises 200-300 species of which only five have been used as cultural plants. In the Czech Republic, white lupine (L.albus), narrow-leafed lupine (L. angustifolius) and yellow lupine (L. luteus) are currently used for both feed and food purposes.

The thin root system with its deep penetration of up to $20 \mathrm{~cm}$ bellow the surface, enabling nutrient uptake from deeper layers, are some of the major advantages of lupine plants (Anonymous 2007). Lupine growth is promoted by bacteria in the root system that can fix nitrogen from the atmosphere and transform it into more readily available ammonia. Lupines are nodulated by soil bacteria that can, under favourable conditions, provide all the nitrogen needed. The nodules are able to fix 160-200 kg nitrogen/ha during the vegetative period, of which about one half is left in the soil, thus fertilizing plants the following year. Lupine is also able to receive sparingly soluble phosphates from the soil. Potassium is not a limiting element, either. Nitrogen fertilizers are only applied in very low productive soils at the rate of $10-15 \mathrm{~kg} / \mathrm{ha}$. Increased sensitivity to the complex of root and cervical diseases and susceptibility of stems to mycoses has been observed during the vegetative period. The complex Botrytis cinerea, Fusarium oxysporum and Phoma medicanidis have the worst effects, followed by anthracnosis caused by the fungus Colletotrichum lupinei (Plaskowska et al. 2000; Nirenberg 2002).

White lupine (L. albus) is an autogamous plant. It reaches the height of $0.75-1 \mathrm{~m}$. The flowers are blue or white. The seeds are large, cream in colour with a circular flattened shape, and with a 1,000-seed weight of 350-400 g. Narrow-leafed lupine (L. angustifolius) is $0.40-1 \mathrm{~m}$ high; the flowers are white and blue and the plant has considerably narrow leaflets of palmate compound leaf. Yellow lupine (L. luteus) is predominantly autogamous, $0.40-0.75 \mathrm{~m}$ high with yellow or orange flowers. Both the latter species have round seeds with seed coat colour from white and yellow to brown, mostly with brown or black marbling. The 1,000-seed weight is $130-180 \mathrm{~g}$. The hull accounts for $22 \%$ of lupine seed weight (Anonymous 2007).

\section{Proteins and amino acids}

The seeds of sweet lupine species (L. albus, L. angustifolius, L. luteus) contain 28 to $48 \%$ (an average of about $33-40 \%$ ) crude protein in dry matter, which depends on the species and climatic conditions (Hove 1974; Green and Oram 1983; Sousa et al. 1996; Linnemann and Dijkstra 2002; Sujak et al. 2006). Great differences in the protein content (from $317.1 \mathrm{~g} / \mathrm{kg}$ cv Boruta to $458.8 \mathrm{~g} / \mathrm{kg}$ cv Juno in dry matter) were found in the most frequently cultivated lupine species in Europe by Straková et al. (2006). Seed analysis of L. luteus cv Juno showed crude protein contents in the range of 39.8 to $48.2 \%$ in dry matter (Roth-Maier and Kirchgessner 1993). Variability in protein content is determined by genetic and environmental effects and the year of harvest (Zdunczyk et al. 1996) (Table 1). The profile of amino acids is characterised by a lower level of methionine $(\sim 0.2 \%$ of the seed, $0.66 \mathrm{~g} / 16 \mathrm{~g} \mathrm{~N})$, cysteine $(\sim 0.4 \%$ of the seed, $1.36 \mathrm{~g} / 16$ $\mathrm{g} \mathrm{N}$ ) and lysine (1.46\% of the seed, $4.75 \mathrm{~g} / 16 \mathrm{~g} \mathrm{~N})$ (Petterson 2000). Threonine level reaching $1.15 \%$ is low, and tryptophane content with $2.76 \mathrm{~g} / \mathrm{kg}$ is also low compared to soy (Simon and Jeroch 1999). In contrast, arginine content is markedly higher, reaching 31.0 to $48.0 \mathrm{~g} / \mathrm{kg}$ (Suchý et al. 2005). The highest level of amino acids within the crude protein 
Table 1. Contents of major nutrients in selected cultivars of Lupinus albus, L. angustifolius and L. luteus

\begin{tabular}{|c|c|c|c|c|c|}
\hline & \multicolumn{4}{|c|}{$\%$ of DM } & \multirow[b]{2}{*}{ Reference } \\
\hline & Crude protein & Ether extract & Crude fibre & Starch & \\
\hline & \multicolumn{4}{|c|}{ Lupinus albus } & \\
\hline Wat & 34.0 & 9.9 & 12.9 & & $\begin{array}{c}\text { Zdunczyk et al. } \\
\text { (1996) }\end{array}$ \\
\hline Hetman & 37.0 & 10.4 & 10.7 & & " \\
\hline Bardo & 38.0 & 10.4 & 11.6 & & $"$ \\
\hline L. albus & 37.3 & 8.8 & 13.0 & 7.4 & $\begin{array}{l}\text { Roth-Maier } \\
\text { et al. (2004) }\end{array}$ \\
\hline Hetman & 31.9 & 10.4 & 12.2 & & Gdala et al. (1996) \\
\hline Lublanc & 38.4 & 7.9 & 14.7 & 7.9 & “" \\
\hline Amiga & 37.6 & 7.3 & 13.8 & 8.3 & $\begin{array}{c}\text { Roth-Maier } \\
\text { and Kirchgessner } \\
(1993)\end{array}$ \\
\hline Amiga & 33.7 & 10.8 & 13.4 & & Zralý et al. (2007) \\
\hline Butan & 38.5 & 7.9 & 15.3 & & $\begin{array}{c}\text { Písaříková } \\
\text { et al. (2008) }\end{array}$ \\
\hline \multirow[t]{2}{*}{ White lupine } & 39.1 & 10.4 & 11.6 & & $\begin{array}{l}\text { Petterson et al. } \\
(2000)\end{array}$ \\
\hline & \multicolumn{4}{|c|}{ Lupinus angustifolius } & \\
\hline L. angustifolius & 33.3 & 5.7 & 16.3 & 10.1 & $\begin{array}{l}\text { Roth-Maier } \\
\text { et al. (2004) }\end{array}$ \\
\hline Saturn & 31.2 & 5.6 & 13.5 & & $\begin{array}{l}\text { Gdala et al. } \\
\text { (1996) }\end{array}$ \\
\hline ASL (Australian lupine) & 29.4 & 5.5 & 14.2 & & “" \\
\hline Sonet & 34.0 & 6.1 & 14.0 & 6.8 & $\begin{array}{c}\text { Straková } \\
\text { et al. (2006) }\end{array}$ \\
\hline \multirow[t]{2}{*}{ Australian sweet lupine } & 35.1 & 6.5 & 16.8 & & $\begin{array}{c}\text { Petterson } \\
\text { et al. (2000) }\end{array}$ \\
\hline & \multicolumn{4}{|c|}{ Lupinus luteus } & \\
\hline L. luteus & 43.8 & 5.7 & 16.8 & 4.9 & $\begin{array}{l}\text { Roth-Maier } \\
\text { et al. (2004) }\end{array}$ \\
\hline Amulet & 37.5 & 4.1 & 15.4 & & $\begin{array}{c}\text { Gdala } \\
\text { et al. (1996) }\end{array}$ \\
\hline Cybis & 38.8 & 4.9 & 13.0 & & " \\
\hline Borsaja & 45.7 & 4.6 & 13.9 & $\begin{array}{r}4.1 \\
;\end{array}$ & $\begin{array}{c}\text { Roth-Maier } \\
\text { and Kirchgessner } \\
(1993)\end{array}$ \\
\hline Juno & 45.8 & 4.6 & 15.4 & 3.8 & “" \\
\hline Juno & 45.9 & 5.5 & 14.3 & 4.1 & $\begin{array}{c}\text { Straková } \\
\text { et al. (2006) }\end{array}$ \\
\hline Yellow lupine & 41.8 & 6.2 & 17.7 & & $\begin{array}{c}\text { Petterson } \\
\text { et al. (2000) }\end{array}$ \\
\hline
\end{tabular}

(AA - $97.7 \mathrm{~g} / 16 \mathrm{~g} \mathrm{~N}$ ) was in white lupine characterised by a higher essential amino acid index (EAAI) (about 85\%) as well as chemical score (CS) (about 60.2\%) of restrictive amino acids, and the highest protein efficiency ratio (Sujak et al. 2006). Zralý et al. (2007, 2008) and Písaříková et al. (2008) found the following levels in the seeds of cultivated lupines: crude protein from 336.9 to 435.7 , lysine from 16.4 to 22.6 , methionine 
from 2.6 to 5.0 and threonine from 11.6 to $15.8 \mathrm{~g} / \mathrm{kg}$ DM. Dehulling resulted in the increase of protein and amino acid levels by approximately $13 \%$.

In Lupineus species the sum of amino acids was about $90 \%$ of the value of $\mathrm{N} \times 6.25$. This approximates to a conversion factor of 5.6. Thus about $10 \%$ of the nitrogen present in lupine seed is likely to be of non-protein origin (Petterson 2000). This is similar to the value suggested by Sosulski and Imafidon (1990) for L. albus.

\section{Fibre}

Lupine seeds contain more dietetically beneficial crude fibre compared to other leguminous plants. Lupine seed is notable for its high fibre content and the absence of starch. The fibre in lupine seed is suited as dietary fibre (Johnson and Gray 1993). The reserve carbohydrate is stored in a thickened cell wall to $1 / 3$ of kernel weight, mostly as pectin-like material (little cellulose/hemicellulose). These characteristics are responsible for the cholesterol-lowering properties of fibre.

Lupine fibre can substantially reduce cholesterol level, as well as it can improve bowel function and reduce the intestinal transit time. In lupine species cultivated in Europe, the content of crude fibre ranged from 94.4 to 142.0 and acid detergent fibre (ADF) from 124.2 to $192.2 \mathrm{~g} / \mathrm{kg}$ and was higher compared to soybean according to Straková et al. (2006). Písaříková et al. (2008) found in the seeds of cultivated lupine species markedly lower level of crude fibre (by 75\%) and its components - neutral detergent fibre (NDF - by 70\%), acid detergent fibre (ADF - by 69\%), and acid detergent lignin (ADL - by 99\%) due to dehulling.

The composition of polysaccharides in Lupineus albus L. 2043N was studied by Mohamed and Rayas-Duarte (1995) who found the contents of IDF and SDF in lupine cotyledons $21.5 \%$ and $2.2 \%$, and 86.1 and $1 \%$ in the hulls, respectively. According to Evans and Cheung (1991), the composition of dietary fibre extracted from the hulls or cotyledons of L. angustifolius differs predominantly in the galactose content. Major component of cotyledons is galactose whilst the dominant component of the hull is glucose.

As the term "fibre" is inaccurate and rather related to the analytical conception than to a certain nutrient, attention is paid to its components, i.e. saccharides and oligosaccharides.

\section{Saccharides}

The seeds contain very little starch, with carbohydrates stored in the form of complex polysaccharides in the thick cell walls of the cotyledons, and as cellulose and hemicellulose in the testa (Brillouet and Riochet 1983; Weightman et al. 1994; Petterson 1998; van Laar et al. 1999). Although lupine seed contains low level of starch, values in the range $3.8 \%$ to $10.1 \%$ (Roth-Maier and Kirchgessner 1993; Roth-Maier et al. 2004; Straková et al. 2006) or $1 \%$ to $2 \%$ (Bagger et al. 1998) have been mentioned in the literature. These differences might be due to the analytical method used. Certain disadvantages can be obtained using the Ewers polarimetric method in which partial hydrolysis of fibre fractions may occur resulting in higher values obtained. The enzymatic method offers lower values but more reliable results.

Major constituent of polysaccharides are non-starch polysaccharides (NSP) - polymers of galactose, arabinose and uronic acid (Jean-Marc and Carre 1989). Non-starch polysaccharides are an excellent source of food fibre with high water binding (up to eight-fold volume).

Production responses to the inclusion of lupine seeds in pig diets can be impaired if the overall NSP content of the diets is high. Van Barneveld (1997) determined the apparent ileal amino acid digestibility and digestible energy (DE) of wheat, barley, triticale and 
lupine seeds and then formulated a diet to contain $500 \mathrm{~g} / \mathrm{kg}$ of each cereal, respectively, and $350 \mathrm{~g} / \mathrm{kg}$ lupines. The diets were equalized for ileal digestible amino acids with lysine limited at $0.40 \mathrm{~g} / \mathrm{MJ} \mathrm{DE}$, and the growth rates of pigs fed on these diets were determined. A highly significant difference was observed in the empty-body-weight gain of pigs fed on the diet containing lupines plus barley compared with lupines plus wheat and lupine plus triticale, respectively. Based on the original diet formulations, all pigs should have grown at the same rate if the apparent ileal lysine digestibility and DE values were additive when the lupines and cereals were combined in a mixed diet. It appears that the antinutritive effects of soluble and insoluble NSP from lupines and barley are amplified when these feed ingredients are combined.

The high level of readily fermentable NSP in lupines has a significant effect on the way that energy is derived from this legume by livestock. In single-stomached animals, energy contained in monosaccharides absorbed from the small intestine is utilized differently from volatile fatty acids derived from fermentation taking place in the hindgut. In pigs, van Barneveld et al. (1995) demonstrated that as the level of lupines increases in the diet, digestible energy does not change, but the proportion of energy digested in the end of the small intestine (which will influence net energy) significantly decreases. Noblet et al. (1998) suggested that lupines are an excellent energy source for pigs in spite of their high rate of digestion in the hindgut.

\section{Oligosaccharides}

Lupine seeds contain significant levels of oligosaccharides of the raffinose family. Oligosaccharides $-\alpha$-galactosides include especially raffinose, stachyose, verbascose and ajugose. According to the data reported by Saini (1989), white lupine seeds contain from 7 to $14 \% \alpha$-galactosides, whereas in the seeds of other lupine species, their levels can reach up to $20 \%$. The most abundant oligosaccharide was stachyose $(2.8 \%)$, followed by saccharose $(1.8 \%)$ raffinose $(0.4 \%)$, and verbascose $(0.3 \%)$. Verbascose plus stachyose (3.1\%) content was lower than literature reports for soybeans $(4.6 \%)$ (Mohamed and Rayas-Duarte 1995). Zdunczyk et al. (1996) found in white lupine species 7.1 to $8.6 \%$ $\alpha$-galactosides in dry matter. The results indicate that different conditions of cultivation and harvest in particular years can affect the oligosaccharide content in the seeds of the same variety. The content of $\alpha$ - galactosides differs among lupine species from about 60 $\mathrm{g}$ in L. angustifolius to $105 \mathrm{~g} / \mathrm{kg} \mathrm{DM}$ in L. luteus (Gdala el al. 1997). Similar content of $\alpha$-galactosides was found by Roth-Maier et al. (2004) in L. angustifolius and L. luteus (40.8 a $73.5 \mathrm{~g} / \mathrm{kg}$ organic matter). In L. albus cv Amiga, Zralý et al. (2007) found $\alpha-$ galactosides level of $42.2 \mathrm{~g} / \mathrm{kg} \mathrm{DM}$.

Alfa-galactosides cannot be metabolised in the small intestinal tract by endogenous enzymes from the animal due to absence of $\alpha$ - (1.6) galactosidase activity in the intestinal mucosa (Gitzelman and Auricchio 1965). High levels of raffinose oligosaccharides may have a number of negative effects on the nutritional value of lupines. These may include (1) interference with the digestion of other nutrients in the small intestine; (2) decreased dietary net energy contributions due to a higher proportion of hindgut fermentation (Taverner et al. 1985); (3) anaerobic fermentation of these sugars in the hindgut resulting in increased gas production; and (4) an osmotic effect of these oligosaccharides in the intestine. Extraction of oligosaccharides from lupines has been shown to improve the DE content for growing pigs (van Barneveld et al. 1996). Ethanol extraction significantly improved $(P<0.05)$ the digestion of all amino acids in both L. angustifolius and L. albus. These results suggest that oligosaccharides are hindering the digestion of amino acids in the small intestine of pigs fed on diets containing lupines.

As a result of impaired intestinal function (flatulence, osmotic effect, fluid retention, 
dysbacteriosis), lower nutrient and energy conversion as well as health disorders and lower performance occur (Batterham 1992; Veldman et al. 1993; Gdala et al. 1997).

Although galactosides are responsible for the flatulent effect, their apparent prebiotic effect is high. Surprisingly, $\alpha$-galactosides (and some other oligosaccharides) are used as additives into functional foods. They show prebiotic characteristics as they serve as a substrate for bacterial microflora, stimulating the growth and activity of bacteria in the colon, which is beneficial for the host. These oligosaccharides also influence the sensory characteristics (taste, texture and colour) of foodstuffs; they are low-energetic, their characteristics are similar to those of fibre, and are evidently anti-carcinogenic. Their industrial application into the functional foodstuffs has already been realised (Guillon and Champ 2002).

\section{Lipids}

The fact that $\alpha$-galactosides are to a large extent fermented in the colon can cause flatulence as well as insufficient net energy uptake from lupine seeds, despite their high gross and digestible energy value. The data of Fernandez and Batterham (1992) show that the net energy of soybean oilmeal is equal to $52 \%$ of its gross energy content, whereas that of the narrow-leaved lupine only $43 \%$. The high digestibility of lupine nutrients in the entire digestive tract, which is the basis for calculating the energy value of feeds for pigs, may lead to overestimation of the energy value of lupine, especially for younger animals. This problem is more important in respect to yellow lupine, which in comparison with white or narrow-leaved lupine seeds, contains more seed hulls and $\alpha$-galactosides (Saini 1989). This suggests that the dehulling of seeds and consequent elimination most of the $\alpha$-galactosides may increase the energy value of these seeds for pigs. Another way is supplementation of lupine diets with fat. The positive effect of increasing the energy level in the diets of pigs on protein synthesis and weight gains has been found in numerous studies (Donovan et al. 1993; De Greef et al. 1994; Flis et al. 1996; Zralý et al. 2007).

The oil content of lupine seed ranges from 9 to $15 \%$ in L. albus (Pate et al. 1985). Lupine oil is high in polyunsatured fatty acids and contains a high level of vitamin $\mathrm{E}$ and low levels of linolenic acid, which minimize the potential for rancidity. The content of crude fat in seeds ranges between 5 and 13\% (Dijkstra et al. 2003). High proportion (up to 80\%) of unsaturated fatty acids, i.e. oleic acid and linoleic acid has been reported by Yanez et al. (1983), Erbas et al. (2005), and others. There is little variation in the composition of the oil fraction in seed of $L$. angustifolius grown in Australia with the major components being palmitic $(11 \%)$, oleic $(33.5 \%)$, linoleic $(37.1 \%)$ and linolenic $(5.3 \%)$ acids (Petterson 2000). In lupine species which are most frequently cultivated in Europe, the content of crude fat ranges from 47.6 to $117.6 \mathrm{~g} / \mathrm{kg}$ in the original sample (Straková et al. 2006). Zralý et al. (2007, 2008) and Písaříková et al. (2008) found the fat content of 107.7 $\mathrm{g} / \mathrm{kg}$ in the white lupine variety Amiga, and in the variety Butan the fat content was 79.1 and $102.3 \mathrm{~g} / \mathrm{kg}$ DM in whole and dehulled seed, respectively. The total sum of unsaturated fatty acids was $87.5 \%$ (Amiga) and 89.2 or $89.3 \%$ (Butan). No effect of dehulling was found on the total sum of unsaturated fatty acids.

\section{Mineral substances}

Of macroelements, the analyses confirmed the presence of potassium, phosphorus, calcium, magnesium and a low level of sodium. The manganese content of seeds was relatively high, ranging from 0.44 to $1.45 \mathrm{~g} / \mathrm{kg}$ (Zdunczyk et al. 1996). Manganese level of $896 \mathrm{mg} / \mathrm{kg}$ was found in L. albus. L. albus, in contrast to L. angustifolius, appears to accumulate high levels of manganese, which can approach toxicity concentrations for some monogastric species (White et al. 1981; Petters on 2000). The following levels of elements were found in the original matter of lupines cultivated in Europe: calcium 2.10 
to 4.66 , phosphorus 4.29 to 7.20 , magnesium 1.20 to $2.25 \mathrm{~g} / \mathrm{kg}$, potassium 8.6 to 11.1 and sodium 0.1 to $0.2 \mathrm{~g} / \mathrm{kg}$ (Zeman et al. 1995).

\section{Vitamins}

The reported vitamin levels in $\mathrm{mg} / \mathrm{kg}$ in Australian lupines (ASL) are as follows: $\beta$-carotene 3.5 , thiamin 5.3 , riboflavin 2.8 , biotin 0.04 , folic acid 0.4 , choline 3035 , niacin 36 , panthotenic acid 1.6 and $\alpha$-tocopherol 2.2. High level of $\alpha$-tocopherol up to $4.2-4.6 \mathrm{mg} /$ $\mathrm{kg}$ is reported in the cultivars Merrit and Gungurru (Petterson 2000).

\section{Antinutritive substances}

The proportion of antinutritive substances in newly selected sweet lupine varieties markedly decreased compared to bitter lupine varieties and therefore these varieties can safely be fed to ruminants and monogastric animals (Aniszewski et al. 2001; Ciesiolka et al. 2005). Antinutritive substances comprise predominantly chinolizidine alkaloids (lupineidin - spartein, lupanin, lupinein and others), glycosides (lupineid, albin, multiflorin, anagyrin and others). Further, these can include trypsin and chymotrypsin inhibitors, tannins, phenolic substances, lectins and some others. The typical alkaloid profile in Australian lupines is lupanin $42-59 \%, 13$ - hydroxylupanin $24-45 \%$, angustifolin $7-15 \%, \alpha$-isolupanin $1-1.5 \%$ and traces of other alkaloids. Trypsin inhibitor activity is less than $0.3 \mathrm{mg} / \mathrm{kg}$ and chymotrypsin inhibitor activity is less than $0.6 \mathrm{mg} / \mathrm{kg}$. The tannins are concentrated in the seed coats (hulls), therefore dehulling will minimise any adverse effects. However, the concentration of condensed tannins is so low in lupines $(\sim 0.01 \%)$ that it is unlikely to impair protein utilisation by any animal species (Petterson 2000).

\section{Increase of nutritive value of seeds}

Lupine seeds can be used as a supplement to feed compounds following mechanical treatment by grinding or crushing. It is advantageous that lupine seeds, in contrast to soybeans, do not require heat treatments. Improvement of the nutritive value of lupine can promisingly be obtained by the increase of lysine and methionine content, decrease of fibre content, and by reduction of the side effects of NSP using exogenous enzymes. The level of limiting amino acids can be increased either by natural selection or genetic intervention. Insertion of the sunflower gene encoding sulphur-containing albumin carried out by Molvig et al. (1997) resulted in transgenic lupine whose seeds contained $3.9 \mathrm{~g}$ methionine $/ \mathrm{kg}$ DM compared to $1.7 \mathrm{~g}$ in the parental cultivar grown in an identical stand. Positive results were also obtained by Ravidran et al. (1998) in fattening of broiler chickens.

As the seed coats account for 15 to $22 \%$ of seed weight, either breeding for a thinner hull or dehulling can be considered as a method of obtaining better quality feeds with a higher content of proteins and energy and lower proportion of crude fibre. However, data from the literature concerning the effect of seed dehulling on digestibility of protein, amino acids and energy, or on performance characteristics are rather inconsistent (Fernández and Batterham 1995; Flis et al. 1996; Gdala et al. 1996; Noblet et al. 1998; King et al. 2000). Supplementation of exogenous enzymes to exclude possible negative effects of non-starch polysaccharides and oligosaccharides on amino acid digestion and utilisation of feed energy appears as an efficient method.

Very few data are available on the influence of enzymes in combination with lupine in the diets of pigs. Roth-Maier et al. (1994) did not confirm a positive effect of supplementation of the enzymatic preparation Roxazyme G (xylanase, cellulase, glucanase and pectinase) at the rate of $200 \mathrm{mg} / \mathrm{kg}$ lupine the performance of piglets. Flis et al. (1998) found no significant effect of application $1 \mathrm{~g}$ Porzyme $/ \mathrm{kg}$ of diet with the inclusion of L. albus. On the other hand, Gdala et al. (1997) found that supplementation of $\alpha$-galactosidase 
( $5 \mathrm{~g} / \mathrm{kg}$ feed) in pig diet (L. luteus, L. angustofolius) resulted in significant improvement of digestibility of the raffinose type oligosaccharides and a positive effect on ileal digestibility of most amino acids $(P<0.05)$. Similar significant increase of feed efficiency was reported by Roth-Maier et al. (2004) following application of xylanase $(0.5 \mathrm{~g} / \mathrm{kg}$ feed $)$ into the lupine diet of pigs at finishing. In this respected, the results are promising, however, further investigations are needed to test other enzyme application and their dosing.

\section{Production efficiency of lupine in pigs}

Data on the effect of lupine on production efficiency in pigs has not always been consistent either. Decreased intake of feeds and decreased growth rate were observed in pigs with a diet containing 150-430 g/kg seeds L. albus (Batterham 1992; Donovan et al. 1993; Roth-Maier and Kirchgessner 1993; Zettl et al. 1995). Van Nevel et al. (2000) and King et al. (2000) found that a 30\% proportion of white lupine in feed compound resulted in decreased feed intake, lower conversion of nutrients and growth depression. King et al. (2000) failed to confirm the positive effect of seed dehulling and amino acid supplementation, thus considering possible negative effect of antinutritive substances, such as alkaloids, $\alpha$-galactosides or high level of manganese (White et al. 1981; Roth-Maier and Kirchgessner 1993; Petterson 2000). In contrast, Gdala et al. (1996) did not observe growth depression in pigs fed diet with L. angustifolius (410 g/ $\mathrm{kg}$ of diet), compared to the diet based on barley and soybean. Positive results with yellow lupine, variety Juno, were also obtained by Flis et al. (1996). The nutritive value of whole and dehulled lupine was studied in fattening pigs by Fernández and Batterham (1995) who did not confirm the positive effect of dehulling. The effect of dehulling on digestive utilisation of nutrients and energy content of digestible or metabolisable energy of L. angustifolius was studied in fattening pigs and gilts by Noblet et al. (1998). In whole seed, dehulled seed, and hulls they found a digestibility coefficient of energy of 77,81 , and $40 \%$ in experiments with growing pigs and 85,89 and $78 \%$ in adult sows, respectively. The corresponding digestible energy contents were 15.7, 16.8, 7.3, 17.3, 18.6 and $14.1 \mathrm{MJ} / \mathrm{kg}$ of dry matter. Higher digestibility of fibre was found in gilts compared to growing pigs (40\% in growing pigs and $90 \%$ in adult sows). High coefficient of protein digestibility $(>90 \%)$ but lower digestibility of energy $(\sim 60 \%)$ is reported for sweet lupines (Petterson 2000).

The nutritive value of diets with a different proportion of cultural lupines ( $L$. angustifolius and albus) for fattening pigs was investigated by Zralý et al. (2006, 2007, 2008) and Písaříková et al. (2008). In the experimental diets, dehulled cultivar Sonet made up 10\%, whole seed cultivar Amiga 20\%, and whole or dehulled seeds of the cultivar Butan replaced $50 \%$ or $100 \%$ protein of soybean extracted meal. The testing of the cultivar Amiga gave non-significantly higher live weight gains and higher feed efficiency in pigs fed the diets supplemented with amino acids and fat $(0.88 \mathrm{~kg} /$ day, $2.55 \mathrm{~kg} / \mathrm{kg})$ compared to the control diets containing animal protein $(0.83$ $\mathrm{kg} /$ day, $2.75 \mathrm{~kg} / \mathrm{kg})$ or soybean $(0.86 \mathrm{~kg} /$ day, $2.66 \mathrm{~kg} / \mathrm{kg})$. In the starter diets with the cultivar Butan, the mean daily gain was non-significantly lower by 1.5 to $6.2 \%$ compared with soybean, however, in the experimental grower and finisher diets, the performance and feed efficiency were higher compared to the control. The authors confirmed that in the diets for fattening pigs, protein of animal origin or soybean can be completely supplemented by lupine, provided that the diets are balanced with limiting amino acids, and the nutritive value is increased by fat supplementation and dehulling. No antinutritive effect has been observed at the above proportions of lupines in the experimental diets. 


\section{Nutriční hodnota lupiny $\mathbf{v}$ dietách pro prasata - review}

Semena sladkých druhů lupiny (Lupineus species) jsou v poslední době stále častěji využívána jako zdroj proteinů nahrazující v krmných směsích živočišné bílkoviny nebo sóju. Semena obsahují v sušině průměrně 33 až $40 \%$ hrubého proteinu, obsah tuku je v rozmezí od 5 do $13 \%$. Aminokyselinové složení je poměrně výhodné, poněkud nižší je obsah lysinu $(1,46 \%)$ a methioninu $(0,22 \%)$. Hlavní zásobní sacharidy v semenech jsou $\beta$-galaktany, které tvoří většinu materiálu buněčných stěn zrna, celulózy a hemicelulózy u silných vrstev osemení. Semena lupiny obsahují okolo $40 \%$ neškrobových polysacharidů (NSP) a zanedbatelné množství škrobu. U sladkých lupin je udáván vysoký koeficient stravitelnosti proteinu $(>90 \%)$, ale nižší stravitelnost energie $(\sim 60 \%)$. Lupiny obsahují zanedbatelné množství inhibitorů trypsinu, proto nevyžadují tepelné ošetření před použitím jako složka krmiva pro monogastrická zvířata. Účinnost lupiny ve výživě prasat charakterizují ne vždy jednoznačně pozitivní výsledky v růstu a konverzi krmiva, a to jak při použití mechanických úprav tak při suplementaci enzymů. Výsledky produkční účinnosti dosažené při ověřování kulturních lupin (L. albus, L. angustifolius) u prasat byly příznivé za předpokladu vybalancování chybějících živin nebo odslupkování. Předkládaný článek shrnuje domácí i zahraniční poznatky o nutriční hodnotě semen kulturních lupin, zabývá se možnostmi zvýšení jejich nutriční a produkční účinnosti ve výživě prasat.

\section{Acknowledgements}

The study was supported by the Ministry of Agriculture of the Czech Republic (Projects No. QG 60142 and No. MZe 0002716201). The translation of the manuscript by Ing. Jarmila Ondráčková of the Veterinary Research Institute, Brno, Czech Republic is gratefully acknowledged.

\section{References}

Aniszewski T, Ciesiolka D, Gulewicz K 2001: Equilibrium between basic nitrogen compounds in lupine seeds with differentiated alkaloid content. Phytochem 57: 43-50

Anonymous 2007: http://www.grainlegumes.com/aep/crops_species. Accessed March 12, 2007

Anonymous 2008: http://www.grainlegumes.com/aep/r_d__projects/healthy_profood/what_is_healthy_profood. Accessed June 13, 2008

Bagger Cl, Bjergegaard C, Sorensen H, Sorensen Jc, Sorensen S 1998: Biorefining lupine seeds to obtain high value protein concentrates and isolates. In Proceedings of the $3^{\text {rd }}$ European Conference on grain Legumes. Valladolid, Spain, pp. 48-49

Batterham ES 1992: Availability and utilization of amino acids for growing pigs. Nutr Res Rev 5: 1-18

Brillouet JM, Riochet D 1983: Cell wall polysaccharides and lignin in cotyledons and hulls of seeds from various lupine (Lupineus L.) species. J Sci Food Agric 34: 861-868

Ciesiolka D, Muzquiz M, Burbano C, Altares P, Pedrosa MM, Wysocki W, Folkman W, Popenda M, Gulewicz K 2005: An effect of various nitrogen forms used as fertilizer on Lupineus albus L. yield and protein, alkaloid and alpha-galactosides content. J Agron Crop Sci 191: 458-463

De Greef KH, Verstegen MWA, Kemp B, Van Der Togt PL 1994: The effect of body weight and energy intake on the composition of deposited tissue in pigs. Anim Prod 58: 263-270

Dijkstra DS, Linnemann AR, Van Boekel TA 2003: Towards sustainable production of protein-rich foods: Appraisal of eight crops for Western Europe. PART II: Analysis of the technological aspects of the production chain. Crit Rev Food Sci Nutr 43: 481-506

Donovan BC, Mcniven MA, Vanlunen TA, Anderson DM, Macleod JA 1993: Replacement of soybean-meal with dehydrated lupine seeds in pig diets. Anim Feed Sci Technol 43: 77-85

Erbas M, Certel M, Uslu MK 2005: Some chemical properties of white lupine seeds (Lupineus albus L.). Food Chem 89: 341-345

Evans AJ, Cheung PCK 1991: Dietary fibre products from lupines. In Martin DJ, Wrigley CV (Eds): Cereals International Cereal Chem Div, R Aust Chem Soc, Parkville, Victoria, Australia, pp. 209-210

Fernández JA, Batterham ES 1992: Lupine seed meal for pigs-how good are they? In Proceedings of $4^{\text {th }}$ Biennial pig industry, Wollongbar, pp. 59-64

Fernández JA, Batterham ES 1995: The nutritive value of lupine-seed and dehulled lupine-seed meals as protein sources for growing pigs as evaluated by different techniques. Anim Feed Sci Technol 53: 279-296

Flis M, Sobotka W, Meller Z 1996: The use of dehulled or fat-supplemented yellow lupine seeds in feeding growing pigs. J Anim Feed Sci 5: 49-61

Flis M, Sobotka W, Zduńczyk Z 1998: Replacement of soyabean meal by white lupine cv. Bardo seeds and the effectivenes of beta-glucanase and xylanase in growing-finishing pig diets. J Anim Feed Sci 7: 301-312 
Gdala J, Jansman AJM, Buraczewska L, Huisman J, Van Leeuwen P 1997: The influence of $\alpha$-galactosidase supplementation on the ileal digestibility of lupine seed carbohydrates and dietary protein in young pigs. Anim Feed Sci Technol 67: 115-125

Gdala J, Jansman AJM, Van Leeuwen P, Huisman J, Verstegen MWA 1996: Lupines (L. luteus, L. albus, L. angustifolius) as a protein source for young pigs. Anim Feed Sci Technol 66: 239-249

Gitzelman P, Auricchio S 1965: The handling of soya alpha-galactosides by a normal and a galactosemic child. Pediatrics 36: $231-235$

Green AG, Oram RN 1983: Variability for protein and oil quality in Lupineus albus. Anim Feed Sci Technol 9: 271-282

Guillon F, Champ MM 2002: Carbohydrate fractions of legumes: uses in human nutrition and potential for health. Br J Nutr 88: 293-306

Hove EL 1974: Composition and protein quality of sweet lupine seed. J Sci Food Agric 25: 851-859

Jean-Marc B, Carre B 1989: Characterization of polysaccharides from white lupine. J Sci Food Agric 34: 861-865

Johnson SK, Gray DM 1993: Strong Ingredients derived from lupine potential for a range of dietary fiber applications. Int Food Ingred 5: 18-23

King RH, Dunshea FR, Morrish L, Eason PJ, Van Barneveld RJ, Mullan BP, Campbell RG 2000: The energy value of Lupineus angustifolius and Lupineus albus for growing pigs. Anim Feed Sci Technol 83: 17-30

Linnemann AR, Dijkstra DS 2002: Toward sustainable production of protein-rich foods: appraisal of eight crops for Western Europe. Part I. Analysis of the primary links of the production chain. Crit Rev Food Sci Nutr 42: $377-401$

Martins JM, Riottot M, De Abreu MC, Viegas-Crespo AM, Lança MJ, Almeida JA, Freire JB, Bento OP 2005: Cholesterol-lowering effects of dietary blue lupine (Lupineus angustifolius L.) in intact and ileo-rectal anastomosed growing pigs fed cholesterol-rich diets. J Lipid Res 46: 1539-1547

Mohamed AA, Rayas-Duarte P 1995: Composition of Lupineus albus. Cereal Chem 72: 643-647

Molvig L, Tabe LM, Eggum BO, Moore AE, Craig S, Spencer D, Higgins TJV 1997: Enhanced methionine levels and increased nutritive value of seeds of transgenic lupines (Lupineus angustofolius L.) expressing a sunflower seed albumin gene. Proc Natl Acad Sci USA 94: 893-898

Nirenberg HI 2002: Description of Colletotrichum lupinei comb. nov. in modern terms. Mycol 94: 307-320

Noblet J, Mancuso M, Bourdon D, Van Barneveld R 1998: Energy value of lupine (Lupineus angustifolius) in growing pig and adult sow (in France). J Rech Porc France 30: 239-234

Pate JS, Williams W, Farrington P 1985: Lupine (Lupineus) spp. In Summerfied R, Roberts EH (eds): Grain Legume Crops, Collins, London, pp. 699-746

Petterson DS 1998: Composition and food uses of lupine. In Gladstone JS, Atkins CA, Hamblin J (Eds): Lupine as Crop Plant: Biology, Production and Utilization. CAB International, Wallingford, Australia, pp. 353-384

Petterson DS 2000: The use of Lupines in Feeding Systems. Review. Asian-Aus J Anim Sci 13: 861-882

Pisarikova B, Zraly Z, Bunka F, Trckova M 2008: Nutritional value of white lupine cultivar Butan in diets for fattening pigs. Vet Med 53: 124-134

Plaskowska E, Kita W, Matkowski K 2000: Investigation on health status of spring barley (Hordeum vulgare L.) and blue lupine (Lupineus angustifolius L.) cultivated in pure sowing and in mixtures. Zesz nauk Akad roln Wrocl 396: 111-125

Ravidran V, Bryden WL, Tabe LM, Higgins TJV, Molvig L 1998: Evaluation of high-methionine transgenic lupines in broiler diets. In Proc Aust Poult Sci Symp 10, University of Sydney, Sydney, Australia, 208 p.

Roth-Maier DA, Böhmer BM, Roth FX 2004: Effects of feeding canola meal and sweet lupine (L. luteus, L. angustifolius) in amino acid balanced diet on growth performance and carcass characteristics of growingfinishing pigs. Anim Res 53: 21-34

Roth-Maier DA, Kirchgessner M 1993: Nährstoffzusammensetzung und Futterwerte verschiedener weißer und gelber Lupinen (Lupineus albus L. und Lupineus luteus L.) für Schwein und Geflügel. Agribiol Res 46: 218-228

Roth-Maier DA, Kirchgessner M 1994: Feeding of white and yellow lupines (Lupineus albus L. and Lupineus luteus L.) in combination with enzyme supplements to piglets (in German). Agribiol Res 47: 312-317

Roth-Maier DA, Paulicks BR, Steinhöfel O, Weiss J 2004: Inhaltstoffe, Futterwert und Einsatz von Lupinen in der Nutztierfütterung (in German), www.ufop.de/downloads/RZ_Praxisinfo_Lupine_071004.pdf. Accessed October 7, 2004

Saini HS 1989: Legume seed oligosaccharides. In Van Der Poel TFB, Huisman J, Lienr IE (Eds): Recent Advances of Research in Antinutritional Factors in Legume Seeds. Pudoc, Wageningen, pp. 329-341

Simon O, Jeroch H 1999: Feed raw materials part 2 - the up-and-coming legumes. Feed Technol 3: 29-32

Sosulski FW, Imafidon GI 1990: Amino acid composition and nitrogen-to-protein conversion factors for animal and plant foods. J Agric Food Chem 38: 1351-1356

Sousa IMN, Morgan PJ, Mitchell JR, Harding SE, Hill SE 1996: Hydrodynamic characterization of lupine proteins: Solubility, intrinsic viscosity, and molar mass. J Agric Food Chem 44: 3018-3021

Suchý P, Straková E, Zralý Z, Písaříková B, Trčková M, Herzig I 2005: Lupine seeds as a source of protein (in Czech). Farmář 2: 37-40

Sujak A, Kotlarz A, Strobel W 2006: Compositional and nutritional evaluation of several lupine seeds. Food Chem 98: 711-719 
Straková E, Suchý P, Večerek V, Šerman V, Mas N, Jůzl M 2006: Nutritional composition of seeds of the genus Lupineus. Acta Vet Brno 75: 489-493

Šikula J, Zubrický J 1964: Veterinary botany and fodder growing (in Czech). Státní zemědělské nakladatelství Praha, $537 \mathrm{p}$.

Taverner MR, Curic DM, Rayner CJ 1985: A comparison of the extent and site of energy and protein digestion of wheat, lupine and meat and bone meal by pigs. J Sci Food Agric 34: 122-128

Van Nevel C, Seynaeve M, Van De Voorde G, De Smet S, Van Driessche E, De Wilde R 2000: Effects of increasing amounts of Lupineus albus seeds without or with whole egg powder in the diet of growing pigs on performance. Anim Feed Sci Technol 83: 89-101

Van Barneveld RJ, Baker J, Szarvas SR, Choct M 1995: Effect of lupine kernels on the ileal and faecal digestibility of energy by pigs. In Hennessy DP, Cranwell PD (eds): Manipulating Pig Production. Australasian Pig Science Association (APSA), Canberra, Australia, pp. 30-37

Van Barneveld RJ, Olsen LE, Choct M 1996: Effect of lupine oligosacharides on energy digestion in growing pigs. Proc Nutr Soc Aust Annu Conf, p. 20

Van Barneveld RJ 1997: The availability of lysine in L. angustifolius (groun whole seed and kernel) and $L$. albus (ground whole seed and kernel) relative to soybean meal in wheat based diets fed to growing pigs. In Van Barneveld RJ (eds): Understanding the nutritional value of lupines. Pig Research and Development Corporation, Canberra, Australia, pp. 14-18

Van Barneveld RJ 1999: Understanding the nutritional chemistry of lupine (Lupineus sp.) seed to improve livestock production efficiency. Nutr Res Rev 12: 1-30

Van Laar H, Tamminga S, Williams BA, Verstegen MWA, Engels M 1999: Fermentation characteristics of cell wall sugars from soya bean meal, and from separated endosperm and hulls of soya beans. Anim Feed Sci Technol 79: 179-193

Weightman RM, Renard CMGC, Thibault JF 1994: Structure and properties of the polysaccharides from pea hulls. I: Chemical extraction and fractionation of the polysaccharides. Carb Polym 24: 139-148

Veldman A, Veen WAG, Barug D, Van Paridon PA 1993: Effect of alpha-galactosides and alpha-galactosidase in feed on ileal piglet digestive physiology. J Anim Physiol Anim Nutr 69: 57-65

White CL, Robson AD, Fisher HM 1981: Variation in nitrogen, sulphur, selenium. cobalt, manganese, cooper and zinc contents of grain from wheat and two lupine species grown in a range of Mediterranean environments. Aust J Agric Res 32: 47-59

White CL, Staines VE, Staines MVH 2007: A review of the nutritional value of lupines for dairy cows. Aust J Agric Res 58: 185-202

Yanez E, Ivanovic D, Owen DF, Ballester D 1983: Chemical and nutritional evaluation of sweet lupines. Ann Nutr Metab 27: 513-520

Zdunczyk Z, Juskiewicz J, Flis M, Amarowicz R, Krefft B 1996: The chemical composition and nutritive value of low-alkaloid varieties of white lupine. 1. Seed, cotyledon and seed coat characteristics. J Anim Feed Sci 5: 63-72

Zeman L, Šimeček K, Krása A 1995: Tables of nutritional values of feeds (in Czech). VÚVZ Pohořelice, 465 p.

Zettl A, Lettner F, Wetscherek W 1995: Use of white sweet lupine seed (Lupineus-albus var Amiga) in a diet for pig fattening (in German). Bodenkultur 46: 165-173

Zralý Z, Písaříková B, Trčková M, Doležal M, Thiemel J, Simeonovová J, Jůzl M 2008: Replacement of soya in pig diets with white lupine cv. Butan. Czech J Anim Sci 53: 418-430

Zralý Z, Písaříková B, Trčková M, Herzig I, Jůzl M, Simeonovová J 2006: Effect of lupine and amaranth on growth efficiency and health, carcass characteristics and meat quality of market pigs. Acta Vet Brno 75: 451460

Zraly Z, Pisarikova B, Trckova M, Herzig I, Juzl M, Simeonovova J 2007: Effect of white lupine on the performance, health, carcass characteristics and meat quality of market pigs. Vet Med - Czech 52: 29-41 